\title{
ANALISIS KOMPETENSI GURU DALAM PENGUASAAN TEKNOLOGI INFORMASI DAN KOMUNIKASI PADA PEMBELAJARAN DI SEKOLAH DASAR NEGERI 2 PURBALINGGA LOR
}

\author{
Sahid Zuhdi Adz Dzaky, Badarudin, Aji Heru Muslim \\ Surel: sahidzuhdi@gmail.com
}

\begin{abstract}
This research focuses on teacher competencies in the use and utilization of information and communication technology in learning. The purpose is to analyze and describe teacher competencies in the use of information and communication technology in learning in a school. The study was conducted using a qualitative descriptive approach. This research was conducted using observation through direct interviews with informants consisting of school principals, class teachers and students. Data validity uses triangulation and reflection. The results show that teachers at SDN 02 Purbalingga Lor have been able and able to use, utilize and collaborate information and communication technology with learning in the classroom. Although in addition there are also constraints both internal and external. Support from related agencies was immediately felt both by the students and by the teachers as users. Principals with their full support also continue to encourage teachers to always innovate, especially in the use of information and communication technology in learning, both in the classroom and outside the classroom.
\end{abstract}

Keywords: Teacher competence, information and communication technology, elementary school.

\begin{abstract}
ABSTRAK
Penelitian ini berfokus pada kompetensi guru dalam penggunaan dan pemanfaatan teknologi informasi dan komunikasi pada pembelajaran. Adapun tujuannya adalah untuk menganalisis dan mendeskripsikan kompetensi guru dalam pemanfaatan teknologi informasi dan komunikasi pada pembelajaran di suatu sekolah. Penelitian dilakukan dengan menggunakan pendekatan deskriptif kualitatif. Penelitian ini dilaksanakan dengan menggunakan observasi melalui wawancara langsung dengan narasumber yang terdiri dari kepala sekolah, guru kelas dan peserta didik. Validitas data menggunakan triangulasi dan refleksi. Hasil menunjukkan bahwa guru di SDN 02 Purbalingga Lor telah mampu dan dapat menggunakan, memanfaatkan serta mengolaborasikan teknologi informasi dan komunikasi dengan pembelajaran di dalam kelas. Meskipun disamping itu terdapat pula kendala-kendala baik yang bersifat internal maupun eksternal. Dukungan dari dinas terkait pun langsung dirasakan baik oleh para peserta didik maupun oleh para guru selaku pengguna. Kepala sekolah dengan dukungan penuhnya juga terus mendorong guru untuk selalu berinovasi khususnya dalam pemanfaatan teknologi informasi dan komunikasi pada pembelajaran, baik itu di dalam kelas maupun di luar kelas.
\end{abstract}

Kata kunci : Kompetensi guru, teknologi informasi dan komunikasi, sekolah dasar. 


\section{PENDAHULUAN}

Pembangunan pendidikan nasional tentunya tak lepas dari kompetensi yang dimiliki oleh guru sebagai tenaga pengajar. Kompetensi inti guru menurut Permendiknas nomor 16 tahun 2007 (2007: 4) yang termaksud didalamnya kemampuan guru perihal pemanfaatan teknologi informasi dan komunikasi untuk kepentingan penyelenggaraan kegiatan pengembangan pendidikan dimana kualifikasi guru Sekolah Dasar (SD) dalam kompetensi pedagogiknya, guru memiliki kemampuan dalam memanfaatkan teknologi informasi dan komunikasi untuk meningkatkan kualitas kegiatan pengembangan peserta didik.

Menurut Lase (2019: 29) Pendidikan mengalami disrupsi yang sangat hebat. Peran guru yang selama ini sebagai satu-satunya penyedia ilmu pengetahuan sedikit banyak bergeser, di masa mendatang peran dan kehadiran guru di ruang kelas akan semakin menantang dan membutuhkan kreativitas yang sangat tinggi. Pemanfaatan berbagai teknologi yang ada pada setiap fase revolusi industri dimanfaatkan pada bidang pendidikan tidak hanya untuk membantu meringankan tugas guru, juga membantu peserta didik dalam memperoleh informasi yang tidak terbatas melalui pemanfaatan internet dan pembelajaran jarak jauh. Bahkan peserta didik dimudahkan dengan munculnya berbagai lembaga kursus berbasis teknologi informasi alias kurus daring yang dapat meminimalisir biaya jika dibandingkan dengan belajar pada lembaga kursus konvensional. Miarso (2011: 528) mengatakan faktor yang berpengaruh atau mendukung terwujudnya proses pembelajaran yang berkualitas dalam upaya mencapai tujuan pendidikan, salah satu diantaranya adalah penggunaan atau pemanfaatan teknologi informasi dan komunikasi dalam proses pendidikan dan pembelajaran.

Revolusi Industri 4.0 sendiri menurut Prasetyo (2018, 22-27) terjadi pada sekitar tahun 2010an melalui rekayasa intelegensia dan internet of thing sebagai tulang punggung pergerakan dan konektivitas manusia dan mesin. Perkembangan dan perubahan yang terjadi pada setiap fase revolusi industri inilah yang mendorong dan mempengaruhi perubahan diberbagai bidang, tak terkecuali pada bidang pendidikan. Pemanfaatan berbagai teknologi yang ada pada setiap fase revolusi industri dimanfaatkan pada bidang pendidikan tidak hanya untuk membantu meringankan tugas guru, juga membantu peserta didik dalam memperoleh informasi yang tidak terbatas melalui pemanfaatan internet dan pembelajaran jarak jauh. Bahkan peserta didik dimudahkan dengan munculnya berbagai lembaga kursus berbasis teknologi informasi alias kurus daring yang dapat meminimalisir biaya jika dibandingkan dengan belajar pada lembaga kursus konvensional.

Berdasarkan pada observasi yang telah dilakukan di Sekolah Dasar Negeri 2 Purbalingga Lor didapati 
bahwa sekolah tersebut telah menerapkan dan mendukung penuh pembelajaran berbasis teknologi informasi dan komunikasi. Seperti telah diterapkan pada kelas VI yang menerapkan pengerjaan Pekerjaan Rumah (PR) yang dikolaborasikan dengan penggunaan aplikasi berbasis teknologi informasi dan komunikasi berupa internet dan pengaksesan gawai yang terkoneksi dengan internet untuk pelaksanaan pembelajaran berupa menjawab kuis (aplikasi kahoot.it).

Perubahan dalam pola pembelajaran menurut Husain (2014: 185), sangat dibutuhkan untuk melakukan pembaharuan dalam sebuah sistem pembelajaran konvensional yang dinilai sudah tertinggal zaman dan tidak relevan dengan dinamika perkembangan zaman yang berkembang semakin cepat dan intensif yang dipicu oleh perkembangan ilmu pengetahuan dan teknologi. Teknologi informasi dan komunikasi dalam pembelajaran berperan sebagai penghubung dalam pelaksanaan transfer ilmu pengetahuan tanpa sama sekali menghilangkan model awal pembelajaran yang berlangsung secara tatap muka di dalam kelas.

Teknologi informasi dan komunikasi yang dimaksud adalah yang mencakup perangkat komunikasi atau aplikasi, meliputi: radio, televisi, telepon selular, komputer dan jaringan perangkat keras dan perangkat lunak, sistem satelit dan sebagainya, serta berbagai layanan dan aplikasi yang terkait dengan mereka, seperti video conference dan pembelajaran jarak jauh. Aplikasi berbasis android juga termasuk dalam teknologi informasi dan komunikasi, hal ini sebagaimana yang telah dilaksanakan di Sekolah Dasar Negeri 2 Purbalingga Lor berupa pengintegrasian pembelajaran dan pemberian pekerjaan rumah dengan teknologi informasi dan komunikasi yang ada.

Sejalan dengan latar belakang yang telah diungkapkan diatas, kajian dalam skripsi ini bertujuan untuk menganalisis kompetensi guru di suatu sekolah dalam penggunaan dan pemanfaatan teknologi informasi dan komunikasi dalam pembelajaran di ruang kelas. Peneliti tertarik untuk meneliti sejauh mana kompetensi guru di Sekolah Dasar Negeri 2 Purbalingga Lor terhadap penguasaan dan integrasi teknologi informasi dan komunikasi dalam pembelajaran.

\section{METODE PENELITIAN}

Penelitian kualitatif menurut Bogdan dan Taylor dalam Moleong (2010: 4) adalah "prosedur penelitian yang menghasilkan data deskriptif berupa kata-kata tertulis atau lisan dari orang-orang dan prilaku yang dapat diamati”. Penelitian kualitatif bertumpu pada latar belakang alamiah secara holistik, memposisikan manusia sebagai alat penelitian, melakukan analisis data secara induktif, lebih mementingkan proses daripada hasil penelitian yang dilakukan disepakati oleh peneliti dan subjek penelitian.

Penelitian ini menggunakan pendekatan kualitatif dan metode 
deskriptif. Penelitian deskriptif menurut Arikunto (2013: 36) adalah penelitian yang menggambarkan kejadian dari sebuah fenomerna yang diteliti, kemudian diambil kesimpulan. Deskriptif yang digunakan dalam penelitian kualitatif bertujuan untuk menggambarkan fenomena berdasarkan data empirik dari hasil wawancara dan observasi yang mendalam.

Penelitian kualitatif menurut Sugiyono (2010: 14) adalah penelitian yang sering disebut sebagai penelitian naturalistik dikarenakan penelitiannya dilakukan pada kondisi yang alamiah (natural setting). Penelitian ini ditujukan untuk memahami fenomenafenomena sosial dari sudut atau perspektif partisipan. Partisipan adalah orang yang diajak wawancara, diobervasi, diminta data, pendapat, pikiran, dan persepsinya. Data yang diperoleh melalui pengamatan, wawancara, dan analisis.

Instrumen penelitian merupakan sebuah alat yang digunakan untuk mengumpulkan informasi yang dikumpulkan pada saat penelitian di lapangan. Sugiyono (2014: 65) dalam bukunya menyatakan bahwa dalam penelitian kualitatif, yang menjadi instrumen adalah peneliti itu sendiri. Jadi peneliti berperan sebagai instrumen kunci dalam penelitian ini, namun peneliti dengan instrumen berupa pedoman wawancara dan pedoman observasi yang mempermudah peneliti dalam melakukan penelitian. Partisipan penelitian merupakan informan yang memberikan data yang berkaitan dengan penelitian kepada peneliti. Partisipan yang menjadi informan dalam penelitian ini yaitu kepala sekolah, guru, dan peserta didik. Partisipan dalam penelitian ini terdiri dari seluruh guru, peserta didik kelas V dan VI, dan kepala sekolah.

Sumber data yang diperoleh dalam penelitian di Sekolah Dasar Negeri 2 Purbalingga Lor yaitu melalui wawancara di sekolah tersebut. Wawancara dilakukan untuk memperoleh data tentang kompetensi guru dalam penggunaan teknologi informasi dan komunikasi pada pembelajaran di sekolah tersebut, tentang bagaimana proses pembelajaran dengan mengintegrasikan teknologi informasi dan komunikasi ke dalam pemblejaran, dan faktor pendukung dan penghambat yang dialami dalam pelaksanaan penggunaan teknologi informasi dan komunikasi pada pembelajaran di Sekolah Dasar Negeri 2 Purbalingga Lor. Jenis sumber data primer yaitu, kepala sekolah, guru dan peserta didik sedangkan sumber data sekunder berupa dokumentasi (foto, dokumen, berkas, dan RPP) terkait dengan kegiatan pembelajaran dengan mengintegrasikan teknologi informasi dan komunikasi di dalamnya.

\section{HASIL PENELITIAN DAN PEMBAHASAN}

Penelitian didahului dengan melakukan observasi langsung ke sekolah yaitu Sekolah Dasar Negeri 2 Purbalingga Lor. Peneliti langsung bertemu dengan kepala sekolah dan memperbincangkan tentang upaya 
sekolah dalam pemanfaatan teknologi informasi dan komunikasi pada pembelajaran di sekolah yang dipimpinnya. Dari wawancara yang dilakukan diketahui bahwa sekolah sudah memiliki fasilitas penunjang dalam pelaksanaan pemanfaatan teknologi informasi dan komunikasi dalam pembelajaran, salah satunya laboratorium komputer. Sekolah ini pernah ditunjuk untuk menjadi salah satu sekolah rintisan bertaraf internasional atau lebih dikenal dengan RSBI. Hal ini yang menyebabkan fasilitas mendasar seperti laboratorium komputer dan fasilitas ketersediaan internet menjadi hal yang mendasar.kemudian di setiap ruang kelas sudah dilengkapi dengan falisitas berupa proyektor LCD yang dapat digunakan guru dengan baik.

Sekolah juga membekali guru dengan sebuah laptop untuk tiap gurunya. Hal ini memudahkan guru dalam membuat dan menyusun pembelajaran yang mengintegrasikan dan memanfaatkan teknologi informasi dan komunikasi dalam pembelajaran yang akan dilakukan. Fasilitas berupa pengeras suara juga diberikan di masing-masing ruang kelas untuk menunjang dan memudahkan guru dalam menerangkan materi yang diberikan. Kemudian hal yang menarik dan bermanfaat bagi guru adalah pengadaan fasilitas internet dengan wifi dengan cakupan yang luas bagi para warga sekolah.

Pada tahap awal wawancara peneliti mengajukan beberapa pertanyaan yang berkaitan dengan pemahaman guru terhadap istilah yang sedang pupuler belakangan ini, yaitu tentang revolusi industri 4.0 khususnya pada bidang pendidikan. Menurut Banu (2018: 22) dalam menghadapi revolusi industri 4.0, terdapat dua jalan yang harus diperisapkan. Berdasarkan wawancara dengan para guru dan kepala sekolah didapati bahwa diantara guru dan kepala sekolah memiliki pandangan yang sama terhadap revolusi industri 4.0 pada bidang pendidikan, yaitu tentang bagaimana suatu lembaga pendidikan bisa dengan matang dan mantap dalam mengadopsi dan memanfaatkan teknologi yang ada khususnya dalam hal pengajaran dan pembelajaran baik di dalam kelas maupun ketika peserta didik mendapat tugas untuk dikerjakan di rumahnya masing-masing. Pemanfaatan teknologi yang ada berupa penggunaan aplikasi seperti quizizz, Kahoot!, dan schoology merupakan salah satu diantaranya. Siswa juga diperbolehkan membawa dan mempergunakan perangkat gadget di ruang kelas, tentunya untuk tingkat tertentu yaitu kelas 6 dan tetap dalam pengawasan para guru.

Sekolah juga telah mendukung penuh usaha para guru dalam rangka melakukan pembelajaran di era revolusi industri 4.0 khususnya pada bidang pendidikan. Pengadaan beberapa perangkat penunjang pembelajaran di tiap-tiap ruang kelas memudahkan para guru dalam melakukan pengajaran dan pembelajaran di ruang kelas. Adapun perangkat teknologi informasi dan 
komunikasi yang ada yaitu proyektor, laptop bagi tiap guru,pengeras suara dan fasilitas internet. Sekolah juga sudah memiliki laboratorium komputer sendiri dan tentunya dengan peminat nomor satu pada ektrakurikuler pembelajaran komputernya. Usaha-usaha yang dilakukan oleh SDN 2 Purbalingga Lor ini juda tak bisa lepas dari visinya yang berupa "Trampil dalam memanfaatkan teknologi" dan juga misinya yang berbunyi "Mengembangkan kemampuan IPTEK secara profesional". Ketercapaian dalam pemanfaatan teknologi informasi dan komunikasi dan juga IPTEK yang terus-menerus diusahakan oleh sekolah merupakan bagian dari visi dan misi sekolah itu sendiri untuk terus berusaha penuh mendukung dan menyongsong pendidikan Indonesia yang sesuai dengan perkembangan zaman, agar sekolah menjadi tempat yang kompatibel bagi generasi saat ini.

Selain dukungan teknis yang telah disediakan dan didukung penuh oleh sekolah sebagai suatu lembaga dan kepala sekolah sebagai pemimpin di lembaga pendidikan tersebut, seorang guru juga terikat dengan peraturan yang dibuat oleh pemerintah pusat yang diwakili langsung oleh kementrian pendidikan. Dalam peraturan Kementrian Pendidikan Nasional (Permendiknas) nomor 16 tahun 2007 tentang Standar Kualifikasi dan Kompetensi guru khususnya pada kompetensi pedagogis guru Sekolah Dasar (SD) didapati bahwa guru mesti memiliki kompetensi berupa kemampuannya dalam memanfaatkan memanfaatkan teknologi informasi dan komunikasi untuk kepentingan pembelajaran. Kompetensi oleh Spencer dalam Moeheriono (2010: 3-4) didefinisikan sebagai karakteristik yang mendasari seseorang berkaitan dengan efektifitas kinerja individu dalam pekerjaannya atau karakteristik dasar individu yang memiliki hubungan kausal atau sebabakibat dengan kriteria yang dijadikan acuan, efektif atau berkinerja prima atau superior di tempat kerja atau pada situasi tertentu. Atau dapat dikatakan bahwa kompetensi merupakan kemampuan yang dimiliki seseorang dimana kemampuan yang dimiliki seorang individu dapat memudahkannya dalam menyelesaikan suatu pekerjaan.

Kompetensi guru menurut Ismail (2010: 54) menjadi salah satu faktor yang berpengaruh terhadap tujuan pembelajaran dan pendidikan di sekolah, namun kompetensi guru tidak kemudian dapat berdiri sendiri, kompetensi guru dipengaruhi oleh faktor-faktor lain seperti latar belakang pendidikan, pengalaman dan lamanya guru dalam mengajar. Pengembangan kompetensi merupakan suatu proses konsolidasi dalam memahirkan seperangkat keterampilan yang dibutuhkan untuk mencapai domain kehidupan. Berdasarkan definisi kompetensi dan kompetensi guru, peneliti mengajukan pertanyaan yang berkaitan dengan pemahaman guru terhadap Permendiknas tentang kompetensi guru sekolah dasar dan bagaimana 
implementasinya pada pendidikan dan pembelajaran di SDN 2 Purbalingga Lor khususnya kompetensi dalam penggunaan teknologi informasi dan komunikasi pada pembelajaran. Dari wawancara yang dilakukan baik dengan guru sebagai subjek utama dan kepala sekolah sebagai subjek sekunder, didapati bahwa guru telah mengetahui dan memahami Permendiknas tersebut. Hal ini didasarkan pada kemampuan guru dalam menggunakan dan memanfaatkan perangkat teknologi informasi dan komunikasi pada pembelajaran, baik itu yang berupa perangkat keras (hardware) maupun yang berupa perangkat lunak (software) yang sudah sesuai dengan peruntukkannya. Untuk perangkat keras sendiri sekolah telah memiliki laboratorium komputer sendiri, seperangkat proyektor LCD, laptop pada tiap-tiap guru, dan printer yang digunakan secara bersama di ruang kantor guru. Sedangkan untuk perangkat lunak seperti software pembelajaran, guru mendapat bantuan baik dari dinas terkait maupun dari dana Bantuan Operasional Sekolah (BOS).

Dari beragam menfaat yang dihadirkan dengan penggunaan teknologi informasi dan komunikasi pada pembelajaran, salah satu yang sangat dirasakan para guru adalah dalam pemberian tugas dan komunikasi dengan siswa di luar sekolah atau diluar jam pembelajaran. Guru di SDN 2 Purbalingga Lor memanfaatkan teknologi berupa komunikasi jarak jauh berbentuk aplikasi whatsapp untuk memberkan tugas dan mengontrol aktivitas peserta didik di luar sekolah. Guru selalu mendapat laporan kegiatan siswa secara realtime dengan terus berkomunikasi via whatsapp dengan orang tua peserta didik di rumah. Tentu, penggunaan smartphone dibatasi hanya boleh digunakan oleh peserta didik yang telah berada di kelas VI. Sedangkan untuk peserta didik kelas I-V penggunaan smartphone sebagai salah satu piranti kelas dalam teknologi informasi dan komunikasi masih harus didampingi oleh orang tuanya. Peserta didik kelas VI juga diperbolehkan untuk membawa smartphone ke dalam ruang belajar atau ruang kelas. Penggunaan smartphone di lingkungan sekolah diperbolehkan oleh sekolah selama masih dalam pengawasan guru dalam penggunaannya dan dimanfaatkan hanya untuk pembelajaran.

Guru selain menggunakan aplikasi whatsapp dalam berkomunikasi dan mengirimkan tugas, guru juga menggunakan aplikasi lainnya seperti Kahoot.it, Ruang guru, Zenius, dan lain sebagainya yang mudah digunakan dan dapat diakses oleh peserta didik. Manfaat lainnya juga mempermudah guru dan siswa saat harus menghadapi suatu wabah berupa pandemi. Pembelajaran tetap dapat terlaksana dengan baik meskipun sekolah diliburkan. Pembelajaran tidak lagi terbatas ruang dan waktu berkat pemanfaatan teknologi informasi dan komunikasi. Guru dengan mudah memberikan materi dan tugas hanya 
dengan menggunakan piranti-piranti yang telah tersedia tanpa perlu khawatir terbatas dalam pembelajarannya. Manfaat yang juga dirasakan oleh peserta didik diantaranya pembelajaran menjadi menyenangkan dan tidak monoton hanya dari satu arah saja atau dari guru semata. Peserta didik bisa leluasa mencari materi dengan menggunakan smartphone yang mereka punya di dunia maya, beragam materi dapat dengan mudah didapatkan oleh para peserta didik, tentu dengan pengawasan para guru di sekolah dan orang tua di lingkungan rumah. Kerjasama dan sinergitas yang baik dari kepala sekolah, guru dan orang tua inilah yang membuat pembelajaran menjadi menyenangkan, efektif dan efisien. Peserta didik tetap menperolah yang mereka mau berupa ilmu pengetahuan yang luas, guru terus memperbaharui pengetahuannya agar bisa menjelaskan yang peserta didik ajukan atau verifikasi pengetahuan, dan orang tua yang tetap menjadi rekan sekolah dalam pengawasan penggunaan smarphone dan teknologi informasi dan komunikasi lainnya di lingkungan rumah.

Selain manfaat dalam penggunaan teknologi informasi dan komunikasi pada pembejaran, juga terdapat kekurangan yang tidak terhindarkan, diantaranya adalah penggunaan dan pemanfatan teknologi informasi dan komunikasi tanpa pengawasan sangat berbahaya bagi peserta didik, maka untuk itulah sekolah terus mewanti-wanti orang tua dan guru untuk tidak lelah mengawasi pesertadidik dalam penggunaan teknologi informasi dan komunikasi. Lain daripada itu kekurangan lainnya adalah memfokuskan penggunaan piranti teknologi informasi dan komunikasi. Peserta didik yang sangat antusias dalam penggunaan teknologi informasi dan komunikasi membuat fokus siswa pada materi yang diterangkan oleh guru berkurang. Solusi yang dihadirkan oleh sekolah adalah dengan membuat siswa akrab dengan teknologi yang ada, sehingga siswa tidak lagi berfokus pada piranti yang dibawa guru, tapi kepada materi menarik yang diberikan guru.

\section{Pembahasan}

Adanya manfaat yang cukup beragam dan berdampak baik bagi pembelajaran dalam penggunaan teknologi informasi dan komunikasi membuat posisi teknologi menjadi hal yang krusial dan dibutuhkan sebagaimana yang dituturkan oleh guru dan kepala sekolah. Kemudahankemudahan yang dihadirkan dengan pemanfaatan teknologi informasi dan komunikasi pada proses pembelajaran baik didalam kelas maupun diluar kelas. Pekerjaan baik berupa pemberian materi pelajaran kepada peserta didik menjadi tidak mainstream lagi, teknologi menghadirkan beragam cara bagi guru untuk berinovasi dalam proses pembelajaran dan transfer ilmu pnegetahuan. Tugas guru lainnya seperti penyusunan Rencana Pelaksanaan Pembelajaran (RPP) yang memang harus disusun tiap harinya hingga pembuatan rapot yang saat ini 
memanfaatkan system online berupa e-Raport. Sehingga guru bisa lebih fokus dalam memberikan pengajaran yang maksimal tanpa terbebani dengan tugas-tugas lainnya. Begitupun dengan para siswa yang menyatakan bahwa dengan penggunaan teknologi informasi dan komunikasi baik didalam kelas maupun diluar kelas telah memudahkan mereka dalam mendapatkan materi yang beragam tidak hanya dari satu sumber semata. Peserta didik juga menyatakan bahwa kemudahan-kemudahan yang dihadirkan oleh adanya teknologi informasi dan komunikasi telah meningkatkan minat mereka terhadap pelajaran yang ada. Hal ini dilatarbelakangi dengan beragam dan variatifnya guru dalam menerangkan suatu materi, baik secara visual dengan menampilkan video pembelajaran maupun menghadirkan kuis yang dapat membuat peserta didik terpacu dalam mencari jawaban. Di masa pandemi seperti saat jurnal ini dibuat juga telah memberikan manfaat nyata. Dimana tempat pembelajaran dan pengajaran tak tebatas dengan ruang dan waktu. Teknologi membuat kelas tak lagi mesti berbentuk ruangan nyata, namun bisa diwakilkan dengan bertatap muka via aplikasi (software) yang tersedia.

\section{SIMPULAN}

Penerapan dan pemanfaatan teknologi informasi di SDN 2 Purbalingga Lor sudah berjalan sebagaimana mestinya. Kendalakendala yang ada dapat teratasi seiring berjalannya waktu. Pengadaan laboratorium komputer dan ketersediaan akses internet di sekolah merupakn nilai tambah bagi sekolah ini. Juga dengan diperkenankannya penggunaan gadget baik berupa smartphone (android/ios) maupun penggunaan laptop dan beragam jenis perangkat teknologi informasi lainnya. Sekolah juga memfasilitasi guru dengan memberikan laptop bagi tiap gurunya. Pengadaan LCD di tiap ruang kelas dan juga pengeras suara juga tak ketinggalam dihadirkan oleh sekolah sebagai bentuk dukungan dan pengadaan fasilitas bagi terlaksanaanya pembelajaran di dalam ruang belajar bagi para peseta didik.

Hadirnya teknologi informasi dan komunikasi pada bidang pendidikan mengubah hal-hal yang sebelumnya terlihat konvensional menjadi suatu hal yang modern dan bermanfaat bagi pembelajara. Peserta didik tak lagi bergantung pada pemberian materi yang hanya berasal dari satu guru saja, namun peserta didik juga akan dengan mudah mendapatkan beragam materi dengan memanfaatkan teknologi informasi dan komunikasi berupa penggunaan beberapa aplikasi pembelajaran yang saat ini tersedia dengan gratis. Tidak hanya gratis semata, namun juga memiliki kualitas materi yang dapat dipertamggungjawabkan. Di era permasalahan ruang dan waktu tak lagi suatu hal yang krusial, pembelajaran dapat terus berlangsung dimanapun dan kapanpun. Beragam kemudahan yang dihadirkan oleh teknologi informasi inilah yang kemudian manfaatnya sangat terasa di masa 
pandemi seperti saat jurnal ini dibuat.

Dimana penerapan sosial distancing maupun phisical ditancing, dan juga penerapan Pembatasan Sosial Berskala Besar (PSBB) di wilayah negara Indonesia. Pembelajaran dan penilaian dapat terus berjalan tanpa hambatan yang berarti. Juga dengan hadirnya teknologi informasi dan komunikasi pada bidang pembelajaran pelaksanaan ujian baik yang sifatnya sekolah maupun nasional dapat diminimalisir kecurangan yang terjadi sehingga harapan menghadirkan para lulusan peserta didik yang berkualitas sedikit banyak akan dicapai dengan langkah-langkah penerapan teknologi informasi dan komunikasi dalam pembelajaran secara tepat dan bertanggungjawab.

\section{DAFTAR RUJUKAN}

Arikunto, S. 2013. Prosedur Penelitian: Suatu Pendekatan Praktik. Jakarta: Rineka Cipta.

Husain, Chaidar. 2019. Pemanfaatan Teknologi Informasi dan Komunikasi dalam Pembelajaran di SMA Muhammadiyah Tarakan. Jurnal Kebijakan dan Pengembangan Pendidikan. 2 (2): 184-192.

Ismail, Ilyas. 2010. Kinerja dan Kompetensi Guru dalam Pembelajaran. Lentera Pendidikan. 13(1): 44-63.

Lase, Delipiter. 2019. Education in the Fourth Industrial Revolution Age. Journal Sciences for Society. 1 (1): 29-43.
Miarso, Yusufhadi. 2011. Menyemai Benih Teknologi Pendidikan. Jakarta: Kencana Prenada Media Group.

Moeheriono. 2010. Pengukuran Kinerja Berbasis Kompetensi. Surabaya: Ghalia Indonesia.

Moleong, L. J. 2010. Metodologi Penelitian Kualitatif. Bandung: Remaja Rosda karya.

Permendiknas. 2007. Peraturan kementrian pendidikan nasional No. 16 tahun 2007 tentang kompetensi guru. Jakarta.

Prasetyo, B., \& Trisyanti, U. 2018. Revolusi Industri 4.0 Dan Tantangan Perubahan Sosial. In Prosiding SEMATEKSOS 3 "Strategi Pembangunan Nasional Menghadapi Revolusi Industri 4.0."

Prasetyo, Banu, Umi Trisyanti. 2018. Revolusi Industri 4.0 dan Tantangan Perubahan Sosial. Prosiding SEMATEKSOS 3. 13 (1): 22-27.

Sugiyono. 2010. Metode Penelitian Pendidikan Pendekatan Kuantitatif, kualitatif, dan $R \& D$. Bandung: Alfabeta. 